JFFI. 2018; 5(2) 289-292

www.jurnal.farmasi.umi.ac.id/index.php/fitofarmakaindonesia

\title{
FORMULASI HAZARD CANDY LOZENGES DARI EKSTRAK BUBUK SIWAK (Salvadora persica L.) UNTUK MENGATASI BAU MULUT
}

\author{
A. Mumtihanah Mursyid*, Andi Amaliah Dahlia \\ Fakultas Farmasi, Universitas Muslim Indonesia \\ *mumtihanah.mursyid@umi.ac.id
}

\begin{abstract}
Siwak is herbs salvadoraceae usually used by the moslems for cleaning the teeth. This study attempts to formulation hard lozanges extract ethanol Salvadora persica L. to overcome fetor. Formulation hard lozanges employing variations concentration sucrose: lactose (F1; 70 \%: 30\%, F2; 50 \%: $50 \%$, F3; $30 \%$ : $70 \%)$ by the method making a molding mixture. Tablet evaluated covering organoleptis testing, uniformity weight, disentegrate time, and hardness test. As for the result of evaluation organoleptis test every formula pink smelling strowberry and tasteless less sweet, test results uniformity weight $(F 1 ; 3,00 \mathrm{~g}, \mathrm{F2} ; 3,04 \mathrm{~g}, \mathrm{F3} ; 3,06 \mathrm{~g})$, disentegrate time test (F1; 9.5 minutes, F2; 6.33 minutes, F3; 5,66 minutes), hardness test $\left(F 1 ; 19 \mathrm{~kg} / \mathrm{cm}^{2}, F 2\right.$; the $\left.20 \mathrm{~kg} / \mathrm{cm}^{2}, F 3 ; 13.5 \mathrm{~kg} / \mathrm{cm}^{2}\right) . O f$ results showing formula 1,2 and 3 qualified testing in pharmaceutical. It can be concluded that salvadora persica can be made into a hard lozanges.
\end{abstract}

Keywords: Hard Lozanges, Persica salvadora L, bad breath

\section{PENDAHULUAN}

Masyarakat Indonesia pada umumnya suka menghindari makan-makanan yang berpotensi menimbulkan bau mulut seperti jengkol, durian, petai dan sebagainya. Bau mulut selain disebabkan oleh bakteri penyebab bau mulut juga disebabkan oleh sisa-sisa makanan yang tertinggal di dalam mulut. Hampir 90 persen penyebab bau mulut adalah bakteri penghasil sulfur yang tinggal di bagian belakang mulut. Hal ini erat kaitannya dengan kebersihan mulut yang tidak terjaga sehingga menyebabkan gigi berlubang, infeksi gusi dan bau mulut.

Karbohidrat yang tertinggal di dalam mulut, permukaan dan bentuk gigi serta mikroorganisme, merupakan penyebab dari karies gigi. Dalam setiap ml air ludah dijumpai 10- 200 juta bakteri. Jumlah maksimum bakteri- bakteri ini dijumpai pada pagi hari atau setelah makan. Salah satu mikroorganisme penting yang dijumpai dalam mulut adalah Streptococcus mutans/Streptococcus viridans (Amoian, B., et al, 2010).

Salah satu alternatif dalam membersihkan gigi adalah menggunakan siwak. Siwak merupakan tumbuhan berfamili salvadoraceae yang biasanya digunakan oleh orang Islam untuk membersihkan gigi (Ahmad, H. \& Rajagopal, K., 2014). Beberapa peneliti diantaranya Sofrata (2007) dan Babpour, S.E (2009) melaporkan adanya efek antibakteri dari siwak terhadap bakteri kariogenik dan pathogen periodontal khususnya spesies Bacterioides serta menghambat pembentukan plak (Noumi et al, 2011).
Penelitian yang lain menyatakan bahwa ekstrak siwak memiliki daya antibakteri terhadap Streptococcus mutans dan S. faecalis (Ahmed, S., 2008). Aktifitas siwak dalam menurunkan pertumbuhan bakteri $S$. mutans disebabkan karena kandungan $\mathrm{SCN}^{-}$yang ketika bereaksi dengan kelompok sulfhidril dalam enzim bakteri akan menyebabkan kematian bakteri (Ahmad, H. \& Rajagopal, K., 2014), sehingga produk asam tidak terbentuk dan $\mathrm{pH}$ plak tidak mengalami penurunan (Amoian, B., et al, 2010).

Namun penggunaan siwak tidak banyak diminati oleh masyarakat. Karena penggunaannya kurang praktis dan tidak menyenangkan karena tekstur yang keras. Karena itulah, dibutuhkan penelitian pengembangan formulasi yang efektif dan efisien serta secara estetika lebih menyenangkan dengan penggunaan lebih praktis dan mudah. Salah satunya adalah membuat tablet hisap cetak (hard candy lozenges) yang lebih praktis, efektif, efisien, murah dan bisa diterima segala umur.

Hard candy lozenges adalah tablet hisap yang dibuat dengan metode molding mixture yaitu meleburkan atau memanaskan gula penyusun permen keras pada suhu yang sesuai hingga meleleh dan mencampurnya dengan bahan tambahan lainnya, selanjutnya menuangnya ke dalam cetakan hingga menjadi massa yang padat dan keras pada suhu kamar (Majekodunmi, 2015). Sukrosa dan glukosa merupakan dua jenis gula yang sering dikombinasikan sebagai bahan penyusun utama 
dalam formulasi hard candy lozenges. Sukrosa berfungsi sebagai bahan pengisi dan pengikat (Majekodunmi, 2015).

Berdasarkan uraian di atas penelitian ini akan dibuat formulasi hard candy lozenges menggunakan variasi sukrosa dan glukosa (kadar sukrosa : glukosa dengan proporsi 70\%:30\%, 50\%:50\%, 30\%:70\%).

\section{METODE PENELITIAN}

Penelitian ini dilakukan secara eksperimental yang merupakan penelitian laboratorium. Adapun tahapan penelitian:

\section{A. Pembuatan Ekstrak Bubuk Siwak (Salvadore persica $\mathbf{L}$.)}

Sebanyak 500 g simplisia kayu siwak yang telah diserbukkan secara maserasi pada suhu $40{ }^{\circ} \mathrm{C}$ menggunakan etanol $96 \%$ selama 3x 24 jam dan diaduk tiap 1 x 24 jam. Kemudian maserat disaring dari ampasnya sehingga diperoleh ekstrak cair, keseluruhan dari ekstrak cair dipekatkan dengan rotary evaporator pada suhu $45^{\circ} \mathrm{C}$ hingga didapatkan ekstrak kental.

\section{B. Formulasi Hazard Candy Lozenges}

Master formula tablet hisap ekstrak bubuk siwak (Salvadore persica L.), dapat dilihat pada tabel 1. Tiap 3 gr tablet mengandung:

Tabel 1. Master Formula Tablet Hisap Ekstrak Etanol Siwak (Salvadore persica L.)

\begin{tabular}{lcccc}
\hline Bahan & Formula & Formula & Formula & Fungsi \\
& $\mathbf{1}$ & $\mathbf{2}$ & $\mathbf{3}$ & \\
\hline Ekstrak $50 \%$ & $0,8 \mathrm{gr}$ & $0,8 \mathrm{gr}$ & $0,8 \mathrm{gr}$ & Zat aktif \\
Sukrosa & $1,75 \mathrm{gr}$ & $1,25 \mathrm{gr}$ & $0,75 \mathrm{gr}$ & Pengisi \& pengikat \\
Glukosa & $0,75 \mathrm{gr}$ & $1,25 \mathrm{gr}$ & $1,75 \mathrm{gr}$ & Pemanis \\
Aquades & $\mathrm{qs}$ & $\mathrm{qs}$ & $\mathrm{qs}$ & pelarut \\
\hline
\end{tabular}

\section{Pembuatan Hard Lozenges}

Ditimbang bahan-bahan. Dipanaskan Aquades hingga $100{ }^{\circ} \mathrm{C}$. Kemudian masukan sukrosa dalam Aquades pada suhu $100{ }^{\circ} \mathrm{C}$. Masukkan Glukosa. Panaskan hingga mencapai suhu $160{ }^{\circ} \mathrm{C}$. Didinginkan pada suhu $90{ }^{\circ} \mathrm{C}$. Lalu didinginkan hingga suhu $90{ }^{\circ} \mathrm{C}$. Kemudian masukan Ekstrak dicampurkan dan diaduk hingga homogen. Kemudian tuang kedalam cetakan dengan berat 3,0 g saat mencapai suhu $85^{\circ} \mathrm{C}$. Larutan didinginkan pada suhu kamar hingga padat dan keras. Ditimbang bahanbahan. Dipanaskan Aquades hingga $100{ }^{\circ} \mathrm{C}$. Kemudian masukan sukrosa dalam Aquades pada suhu $100{ }^{\circ} \mathrm{C}$. Masukkan Glukosa. Panaskan hingga mencapai suhu $160{ }^{\circ} \mathrm{C}$. Didinginkan pada suhu $90^{\circ} \mathrm{C}$. Lalu didinginkan hingga suhu $90{ }^{\circ} \mathrm{C}$. Kemudian masukan Ekstrak dicampurkan dan diaduk hingga homogen. Kemudian tuang kedalam cetakan dengan berat $3,0 \mathrm{~g}$ saat mencapai suhu $85{ }^{\circ} \mathrm{C}$. Larutan didinginkan pada suhu kamar hingga padat dan keras.

\section{Evaluasi hard Lozanges}

Dilakukan Pemeriksaan organoleptik, keseragaman ukuran, keseragaman bobot, uji kerenyahan, uji kekerasan, dan uji waktu hancur.

\section{HASIL DAN PEMBAHASAN}

Siwak merupakan tumbuhan berfamili salvadoraceae yang biasanya digunakan oleh orang Islam untuk membersihkan gigi (Ahmad, H. \& Rajagopal, K., 2014). Beberapa peneliti diantaranya Sofrata (2007) dan Babpour, S.E (2009) melaporkan adanya efek antibakteri dari siwak terhadap bakteri kariogenik dan pathogen periodontal khususnya spesies Bacterioides serta menghambat pembentukan plak (Noumi et al, 2011).

Hard lozanges adalah jenis tablet hisap yang mempunyai bahan utama pembuatannya adalah dengan sukrosa, Laktosa dan air (Ramadhan, 2012). Sukrosa berfungsi sebagai bahan pengikat (Amstrong, 2005). Sukrosa adalah komponen utama hard lozanges yang berguna sebagai pemanis. Konsentrasi sukrosa dalam formula harus diatur secara tepat. Konsentrasi yang terlalu tinggi dapat menyebabkan terjadinya kristalisasi yang terlalu rendah $(75 \%)$ dapat menyebabkan pertumbuhan kapang dan khamir. Sukrosa merupakan bahan utama dalam pembuatan hard lozanges. Sukrosa murni mengalami kristalisasi. Bahan sukrosa yang terdispersi ini akan menyebabkan kristalisasi pada produk akhir (Jackson, 1995). Bila penambahan gula yang terlalu sedikit menyebabkan menjadi lembek (Margono, 2000).

Laktosa merupakan bahan pengisi yang paling banyak di pakai karena tidak bereaksi dengan hampir semua bahan obat baik dalam bentuk hidrat maupun anhidrat. (Lachman dkk, 1994). Laktosa merupakan satu gula yang diperoleh darisusu. Dalam bentuk anhidrat mengandung satu molekul hidrat (DepKes RI, 1995).

Kemudian semua bahan ditimbang dan dicampurkan dan kemudian dilakukan evaluasi tablet yang dimana meliputi uji organoleptis, keseragaman bobot, waktu hancur, dan kekerasan tablet. 
Tabel 2. Hasil Pemeriksaan Organoleptis Tablet Hard Lozenges Siwak (Salvadora persica L.)

\begin{tabular}{cccc}
\hline Organoleptis & Formula 1 & Formula 2 & Formula 3 \\
\hline Rasa & Kurang Manis & kurang manis & kurang manis \\
Aroma & Strowberi & Strowberi & Strowberi \\
Warna & Merah muda mengkilau & Merah muda & Merah muda \\
Bentuk & Bulat dengan & Bulat dengan & Bulat dengan \\
Tekstur & permukaan yang datar & permukaan yang datar & permukaan yang datar \\
\hline
\end{tabular}

Dalam tablet hisap diperlukan uji organoleptis di mana uji organoleptis ini berguna untuk melihat penampilan fisik dari tablet hisap. Dan dari hasil uji organoleptis ini dapat dilihat pada tabel 2. Dalam tabel 2 menunjukan bahwa rasa dari formula 1, 2 dan 3 yang kurang manis. Rasa yang kurang manis dapat ditutupi dengan aroma strowberi dari ketiga formula. Penaroma sangat mendominasi dalam aroma tablet yang dihaasilkan karena ekstrak siwak tidak memberikan aroma dan bau khas yang dapat mengganggu sedian yang dihasilkan. Selain itu, pengujian lainnya yaitu tekstur dan bentuk yang sama untuk setiap formula yaitu tekstur agak keras dan bentuk bulat dengan permukaan yang datar. Bentuk dihasilkan dari alat cetak dengan keseragaman bentuk yang memadai untuk setiap formula.

Tabel.3 Hasil Evaluasi Tablet Hard Lozenges Siwak (Salvadora persica L.)

\begin{tabular}{|c|c|c|c|c|c|}
\hline \multirow{2}{*}{$\begin{array}{c}\text { Evaluasi } \\
\text { Tablet }\end{array}$} & \multicolumn{3}{|c|}{ Formula } & \multirow{2}{*}{ Syarat } & \multirow{2}{*}{ Keterangan } \\
\hline & 1 & 2 & 3 & & \\
\hline $\begin{array}{l}\text { Keseragaman } \\
\text { bobot (gram) }\end{array}$ & $3.00 \pm 0,05$ & $3,04 \pm 0,25$ & $3,06 \pm 0,17$ & $\begin{array}{l}\text { Tidak } \\
\text { boleh } 2 \\
\text { tablet }<5 \% \\
\text { dan 1 } \\
\text { tablet } \\
<10 \%\end{array}$ & Memenuhi \\
\hline $\begin{array}{c}\text { Kekerasan } \\
\text { Tablet } \\
\left(\mathrm{kg} / \mathrm{cm}^{2}\right)\end{array}$ & $19 \pm 1,5$ & $20 \pm 1,6$ & $13,5 \pm 1,3$ & $\begin{array}{c}4- \\
8 \mathrm{~kg} / \mathrm{cm}^{2}\end{array}$ & Memenuhi \\
\hline $\begin{array}{l}\text { Waktu Hancur } \\
\text { (Menit) }\end{array}$ & $9,5 \pm 1,5$ & $6,33 \pm 1,8$ & $5,66 \pm 3,76$ & $5-10$ menit & Memenuhi \\
\hline
\end{tabular}

Dari tabel di atas dapat dilihat bahwa untuk uji keseragaman bobotnya menunjukan untuk ratarata dari formula 1 , formula 2 dan formula 3 berturutturut adalah 3,0 gram, 3,04 dan gram 3,06 gram. Adapun dari hasil rata-rata ketiga formula di atas maka peneliti dapat menentukan penyimpangan beratnya. Diharapkan agar sesuai syarat dari keseragaman bobot tablet. Di mana tidak lebih dari 2 tablet dari masing-masing tablet yang menyimpang sebanyak 5\% dari rata-ratanya dan tidak satupun tablet yang menyimpang sebanyak $10 \%$. Untuk data yang diperoleh (Lihat lampiran) menunjukan bahwa dari bobot tablet formula 1 , formula 2, dan formula 3 itu memenuhi syarat yang telah ditentukan.

Tablet hisap memiliki memiliki kekerasan lebih besar yang setara dengan permen obat keras (hard candy lozanges) yaitu $4-8 \mathrm{kp}$ atau $4-8 \mathrm{~kg} / \mathrm{cm}^{2}$
(Srinur et al., 2014). Dapat dilihat hasil dari tabel di atas menunjukan bahwa nilai rata-rata penguian kekerasan formula 1 , formula 2 dan formula 3 berturut-turut $19,20,13,5 \mathrm{~kg} / \mathrm{cm}^{2}$ yang menunjukkan ketiga formula memenuhi syarat kekerasan yang sesuai untuk sediaan tablet hisap.

Dari hasil evaluasi waktu hancur dapat menunjukan nilai tabel di mana rata-rata waktu hancur tablet hisap ekstrak siwak adalah berturutturut formula 1 , formula 2 dan formula 3 yaitu 9,55 menit, 6,33 menit, dan 5,66 menit. Perbedaan waktu hancur tiap formula dikarenakan perbedaan konsentrasi kombinasi pengisi yaitu semakin rendah konsentrasi dari laktosa dan semakin tinggi konsentrasi dari sukrosa menghasilkan tablet yang lebih kompak dengan waktu hancur yang lebih lama. Hal ini disebabkan oleh karena penggunan 
konsentrasi sukrosa yang dominan menyebabkan pertumbuhan kristal oleh sukrosa sehingga merubah bentuk fisik dari tablet yang dhasilkan. Keseluruhan hasil ini dapat menentukan bahwa tablet hisap ekstrak siwak memenuhi syarat waktu hancur tablet hisap yaitu 7 - 13 menit.

\section{KESIMPULAN}

Berdasarkan hasil penelitian yang diperoleh maka disimpulkan bahwa:

1. Batang Siwak (Salvadora persica L.) dapat dibuat menjadi sediaan tablet hisap (Hard Lozenges).

2. Hard Lozenges ekstrak etanol batang siwak (Salvadora persica L.) yang stabil secara farmaseutika memiliki aktivitas sebagai antibakteri bau mulut.

\section{UCAPAN TERIMA KASIH}

Kepada Fakultas Farmasi, Universitas Muslim Indonesia terkhusus Lembaga Penelitian dan Pengembangan Sumber Daya Manusia Universitas Muslim Indonesia (LP2S UMI).

\section{DAFTAR PUSTAKA}

Amoian, B. et al., 2010, Salvadora Persica Extract Chewing Gum and Probe-bleeding Index, Complement Ther Clin Pract, 11, p. 121123.

Ahmad, H \& Rajagopal, K., 2014, Salvadora Persica L. (Meswak) in Dental Hygiene, The Saudi Journal for Dental Research, Vol 5 (2), p. 130-134.

Ahmed S., 2008, Preliminary Phytochemical and Propagation Trial with Salvadora Persica L., Adric For Res Vol 1 (58), p. 135-138.

Armstrong, N.A., 2005, Sucrose in Rowe C.R., Sheskey, P.J., and Owen, S.C., (Eds)., Handbook of Pharmaceutical Exipients, 5th Edition, 743-747, Pharmaceutical Press, London, UK.

Babpour, S.E., et al., 2009, Antimocrobial Effects of Four Plants on Dental Plageue, J. Med Plants Res, Vol 3(3), p. 132-137.

Depkes RI, 1995, Farmakope Indonesia: Jilid IV, Jakarta.

Jackson, E.B. 1995, Sugar Confectionery Manucfacture, Blackie Academic \& professional, London.

Lachman, L. dkk., 1994, Teori dan Praktik Industri Farmasi, diterjemahkan oleh Suyatmi S., Jakarta, UI Press.
Majekodunmi, 2015, A Review on Lozenges, American Journal of Medicine and Medical Science, Vol. 5 (2), p. 99-104.

Margono. 2000. Metodologi Penelitian Pendidikan. Jakarta: Rineka Cipta.

Noumi, et al., 2011, Antibacterial, Anticandidal and Antioxidant Activities of Salvadora Persica and Juglan Regial Extracts, J Med. Plants Res (17), p. 4138-4146.

Ramadhan, 2012, Pembuatan Permen Hard Candy yang Mengandung Propolis Sebagai Permen Kesehatan Gigi. Universitas Indonesia.

Sofrata, et all., 2007, The Effect of Miswak Extract on Plaque an In vivo Study, Caries Res, 41. P. 451-454. 